\title{
Giant aneurysms of the carotid system presenting as visual field defect
}

\author{
J B PEIRIS AND R W ROSS RUSSELL \\ From the Institute of Neurology, National Hospital for Nervous Diseases, London
}

S UMMARY Visual field loss was the presenting symptom in 19 patients with large intracranial aneurysms of the carotid system. Location of the aneurysm was cavernous, carotid-ophthalmic (two), supraclinoid (nine), anterior communicating (six). Other features were pain and a long history of fluctuating visual loss. Cavernous or carotid-ophthalmic aneurysms mostly caused purely uniocular field loss consistent with optic nerve compression. Supraclinoid aneurysms most often caused a lateral chiasmal syndrome. Anterior communicating aneurysms caused asymmetric compression of one or both optic nerves, the eye contralateral to the feeding artery being more often affected. Carotid ligation appeared to arrest visual deterioration in some patients in the supraclinoid group.

The great majority of all intracranial aneurysms are situated on the carotid artery or the anterior part of the Circle of Willis. Although many of these present either as subarachnoid haemorrhage or ophthalmoplegia, some cause no symptoms throughout life and some enlarge progressively and at a late stage may compress the visual pathways. It is rare for failure of vision to be the presenting symptom; on the other hand for the ophthalmologist seeing a patient with progressive visual field loss an aneurysm must always be considered in the differential diagnosis. We report 19 patients with unruptured parachiasmatic aneurysm presenting initially only with progressive failure of vision with particular reference to the type of field defect and to its significance in diagnosis.

\section{Case material}

There were 19 patients with verified aneurysms all presenting with some degree of visual loss. The patients were divided into four groups according to the site of the aneurysm.

Group 1 comprised two patients in whom the aneurysm arose from the cavernous (extradural) portion of the internal carotoid artery (cavernous group). Group 2 comprised two patients in whom the aneurysm arose from the ophthalmic artery or

Address for reprint requests: Dr RW Ross Russell, Institute of Neurology, Queen Square, London WC1N 3BG.

Accepted 20 June 1980 from the internal carotid artery immediately after piercing the dura adjacent to the origin of the ophthalmic artery (carotid-ophthalmic group). Group 3 comprised nine patients in whom the aneurysm arose from the supraclinoid (intradural) portion of the carotid artery, either in its proximal segment, or at the site of origin of the posterior communicating artery, or at its bifurcation into anterior and middle cerebral arteries (supraclinoid group). Group 4 comprised six patients in whom the aneurysm arose in relation to the anterior communicating artery or the adjacent part of the anterior cerebral artery (anterior communicating group).

The age and sex of the patients, the site and direction of expansion of the aneurysm with associated clinical defects, $x$-ray appearances and the presenting visual field defects were reviewed (tables 1-4, figs 1-5). The site of pressure on the visual pathways was verified at operation or at necropsy. In other patients the site was deduced from biplane angiography (fig 6).

Ten patients were treated surgically, six by carotid ligation in the neck and four by a direct approach to the aneurysm. Follow-ûp information was available on 18 of the 19 patients. Of the eight untreated patients, follow-up periods ranged from six months to seven years (mean 3.7 years). Vision deteriorated in four, was unchanged in two, showed marked fluctuation in one and improved slightly in one. Improvement was defined as a change in acuity of two lines (Snellen) or better, with or without a reduction in field defect. In the five patients who survived carotid ligation follow-up ranged from four months to nine years (mean 3.5 years). Two patients showed improved vision, three were unchanged (fig 7). Only four patients were treated by a direct 
Table 1 Group 1-Cavernous aneurysms

\begin{tabular}{|c|c|c|c|c|c|c|}
\hline \multirow[t]{2}{*}{ Patient data } & \multirow{2}{*}{$\begin{array}{l}\text { Site of } \\
\text { origin }\end{array}$} & \multicolumn{3}{|l|}{ Aneurysm } & \multirow[t]{2}{*}{ Plain X-ray } & \multirow[t]{2}{*}{ Visual fields } \\
\hline & & $\begin{array}{l}\text { Direction of } \\
\text { expansion }\end{array}$ & $\begin{array}{l}\text { Site of } \\
\text { compression }\end{array}$ & $\begin{array}{l}\text { Associated } \\
\text { features }\end{array}$ & & \\
\hline 1. GG 83 yr F & $\begin{array}{l}\text { Petrous-cavernous } \\
\text { ICA (R) }\end{array}$ & $\begin{array}{l}\text { Forwards into } \\
\text { cavernous sinus }\end{array}$ & R optic nerve & $\begin{array}{l}\text { Intermittent } R \\
\text { ocular pain } 4 \text { yr }\end{array}$ & $\begin{array}{l}\text { Erosion of orbital } \\
\text { fissure, optic canal }\end{array}$ & $\begin{array}{l}\text { RVA finger counting } \\
\text { field: general } \\
\text { depression } \\
\text { LVA } 6 / 24 \text { full field }\end{array}$ \\
\hline
\end{tabular}

Table 2 Group 2-Carotid ophthalmic aneurysms

\begin{tabular}{|c|c|c|c|c|c|c|}
\hline Patient data & Site of origin & $\begin{array}{l}\text { Direction of } \\
\text { expansion }\end{array}$ & $\begin{array}{l}\text { Site of } \\
\text { compression }\end{array}$ & $\begin{array}{l}\text { Associated } \\
\text { features }\end{array}$ & Plain X-ray & Visual field defect \\
\hline 3 JL 48 yr F & $\begin{array}{l}\text { ICA at origin of } \\
\text { ophthalmic (L) }\end{array}$ & Upwards & $\begin{array}{l}\text { L Optic n (dis- } \\
\text { placed medially) }\end{array}$ & $\begin{array}{l}\text { Mild L frontal } \\
\text { pain }\end{array}$ & Normal & $\begin{array}{l}\text { LVA Finger count- } \\
\text { ing central scotoma } \\
\text { RVA } 6 / 9 \text { full field }\end{array}$ \\
\hline 4 PD 55 yr F & $\begin{array}{l}\text { ICA at origin of } \\
\text { ophthalmic (R) }\end{array}$ & $\begin{array}{l}\text { Upwards and } \\
\text { medially }\end{array}$ & $\begin{array}{l}\mathbf{R} \text { optic } \mathrm{n} \text { from } \\
\text { below }\end{array}$ & $\begin{array}{l}\text { Recurrent head- } \\
\text { aches. Later } \\
\text { subarachnoid } \\
\text { haemorrhage }\end{array}$ & Normal & $\begin{array}{l}\text { RVA } 6 / 9 \text { lower } \\
\text { nasal loss } \\
\text { LVA } 6 / 6 \text { full field }\end{array}$ \\
\hline
\end{tabular}

Table 3 Group 3-Supraclinoid aneurysms

\begin{tabular}{|c|c|c|c|c|c|c|}
\hline Patient data & Site of origin & $\begin{array}{l}\text { Direction of } \\
\text { expansion }\end{array}$ & $\begin{array}{l}\text { Site of } \\
\text { compression }\end{array}$ & Associated features & Plain X-ray & Visual fields \\
\hline 5 EB 69 yr F & $\begin{array}{l}\text { Proximal segment } \\
\text { ICA (L) }\end{array}$ & $\begin{array}{l}\text { Upwards and } \\
\text { medially }\end{array}$ & $\begin{array}{l}\text { Optic n (L) } \\
\text { chiasma, lateral } \\
\text { side }\end{array}$ & Tinnitus & $\begin{array}{l}\text { Intact sella: } \\
\text { calcification, mural } \\
\text { thrombus }\end{array}$ & $\begin{array}{l}\text { LVA finger count- } \\
\text { ing nasal hemianopia } \\
\text { RVA } 6 / 9 \text { upper } \\
\text { temporal loss }\end{array}$ \\
\hline 6 NU 59 yr F & Terminal ICA (R) & $\begin{array}{l}\text { Upwards and } \\
\text { medially }\end{array}$ & $\begin{array}{l}\text { Chiasma and optic } \\
\text { n from lateral side }\end{array}$ & Nil & $\begin{array}{l}\text { Linear calcification } \\
\text { in wall }\end{array}$ & $\begin{array}{l}\text { RVA 6/12 nasal } \\
\text { hemianopia } \\
\text { LVA 6/9 upper } \\
\text { temporal loss }\end{array}$ \\
\hline $7 \mathrm{JM} 60$ yr M & Terminal ICA (R) & $\begin{array}{l}\text { Upwards and } \\
\text { medially }\end{array}$ & Optic tract lateral & $\begin{array}{l}\text { Ipsilateral } \\
\text { headache }\end{array}$ & $\begin{array}{l}\text { Erosion of sella. } \\
\text { Calcified wall. No } \\
\text { angiographic } \\
\text { filling }\end{array}$ & $\begin{array}{l}\text { RVA } 6 / 9 \text { nasal } \\
\text { hemianopia } \\
\text { LVA } 6 / 12 \text { temporal } \\
\text { hemianopia }\end{array}$ \\
\hline $8 \mathrm{KL} 43$ yr F & $\begin{array}{l}\text { Supraclinoid } \\
\text { ICA (R) }\end{array}$ & $\begin{array}{l}\text { Upwards and } \\
\text { medially }\end{array}$ & $\begin{array}{l}\text { Chiasma and optic } \\
\mathrm{n} \text { from lateral side }\end{array}$ & Morning headaches & $\begin{array}{l}\text { Erosion of } \\
\text { posterior clinoids }\end{array}$ & $\begin{array}{l}\text { RVA finger count- } \\
\text { ing nasal hemianopia } \\
\text { LVA } 6 / 9 \text { temporal } \\
\text { hemianopia }\end{array}$ \\
\hline $9 \mathrm{AC} 62$ yr F & $\begin{array}{l}\text { Supraclinoid } \\
\text { ICA (L) }\end{array}$ & $\begin{array}{l}\text { Upwards and } \\
\text { medially }\end{array}$ & $\begin{array}{l}\text { L optic nerve and } \\
\text { lateral chiasma }\end{array}$ & $\begin{array}{l}\text { Occasional } \\
\text { headaches }\end{array}$ & $\begin{array}{l}\text { Posterior clinoid } \\
\text { erosion }\end{array}$ & $\begin{array}{l}\text { LVA blind } \\
\text { RVA } 6 / 24 \\
\text { Temporal hemian- } \\
\text { opia }\end{array}$ \\
\hline 10 IG 62 yr M & $\begin{array}{l}\text { Supraclinoid } \\
\text { ICA (L) }\end{array}$ & $\begin{array}{l}\text { Upwards and } \\
\text { medially }\end{array}$ & $\begin{array}{l}\text { Chiasma, traction } \\
\text { on both nerves }\end{array}$ & Frontal headache & Normal & $\begin{array}{l}\text { LVA blind } \mathbf{R} \text { finger } \\
\text { counting } \\
\text { Temporal } \\
\text { hemianopia }\end{array}$ \\
\hline 11 EW 60 yr F & $\begin{array}{l}\text { Terminal } \\
\text { carotid (R) }\end{array}$ & $\begin{array}{l}\text { Lobulated; back- } \\
\text { wards, upwards } \\
\text { and medially }\end{array}$ & $\begin{array}{l}\text { Chiasma, } R \text { optic } \\
\text { tract, } R \text { optic } n \\
\text { flattened, } L \text { optic } n \\
\text { swollen }\end{array}$ & $\begin{array}{l}\text { Unilateral } \\
\text { headache }\end{array}$ & Normal & $\begin{array}{l}\text { RVA } 6 / 24 \text { general } \\
\text { depression } \\
\text { LVA blind }\end{array}$ \\
\hline 12 WA 52 yr F & Terminal ICA (R) & $\begin{array}{l}\text { Upwards, medially, } \\
\text { suprasellar mass }\end{array}$ & $\begin{array}{l}\text { Chiasma, opposite } \\
\text { nerve }\end{array}$ & $\begin{array}{l}\text { L frontotemporal } \\
\text { headache }\end{array}$ & $\begin{array}{l}\text { Aneurysm wall } \\
\text { calcified. Dorsum } \\
\text { sellae eroded }\end{array}$ & $\begin{array}{l}\text { RVA } 6 / 12 \text { slight } \\
\text { temporal depression } \\
\text { LVA } 6 / 60 \text { temporal } \\
\text { hemianopia }\end{array}$ \\
\hline
\end{tabular}


Table 4 Group 4-Anterior cerebral anterior communicating aneurysms

\begin{tabular}{|c|c|c|c|c|c|c|}
\hline Patient data & Site of origin & $\begin{array}{l}\text { Direction of } \\
\text { expansion }\end{array}$ & $\begin{array}{l}\text { Site of } \\
\text { compression }\end{array}$ & Associated features & $X$-ray & Visual fields \\
\hline 14 DR 62 yr F & $\begin{array}{l}\text { Anterior } \\
\text { communicating }\end{array}$ & $\begin{array}{l}\text { Downwards } \\
\text { between optic } \\
\text { nerves }\end{array}$ & $\begin{array}{l}\text { Chiasma, } \mathbf{R} \text { optic } \\
\text { nerve (indirectly by } \\
\mathbf{R} \text { ant cereb) }\end{array}$ & Nil & $\begin{array}{l}\text { Filled only from } \\
\text { left side }\end{array}$ & $\begin{array}{l}\text { LVA } 6 / 6 \text { field full } \\
\text { RVA } 6 / 18 \text { central } \\
\text { scotoma spreading } \\
\text { temporally }\end{array}$ \\
\hline $15 \mathrm{JP} 61 \mathrm{yr} \mathrm{M}$ & $\begin{array}{l}\text { Anterior } \\
\text { communicating }\end{array}$ & $\begin{array}{l}\text { Downwards } \\
\text { medially }\end{array}$ & Both optic nerves & $\begin{array}{l}\text { Dementia person- } \\
\text { ality change }\end{array}$ & Filled from $R$ side & $\begin{array}{l}\text { LVA } 6 / 60 \text { temporal } \\
\text { field lost, nasal field } \\
\text { depressed RVA } 6 / 9 \\
\text { temporal } \\
\text { hemianopia }\end{array}$ \\
\hline $16 \mathrm{JE} 48 \mathrm{yr} \mathrm{M}$ & $\begin{array}{l}\text { Anterior } \\
\text { communicating }\end{array}$ & $\begin{array}{l}\text { Downwards } \\
\text { medially }\end{array}$ & Both optic nerves & $\begin{array}{l}\text { L frontal } \\
\text { headaches }\end{array}$ & Filled from $\mathbf{R}$ only & $\begin{array}{l}\mathbf{L} \text { no light perception } \\
\mathbf{R} \text { full field } 6 / 5\end{array}$ \\
\hline 17 GH 34 yr M & $\begin{array}{l}\text { Anterior } \\
\text { communicating }\end{array}$ & $\begin{array}{l}\text { Downwards and } \\
\text { upward }\end{array}$ & $\begin{array}{l}\text { Between both } \\
\text { optic nerves }\end{array}$ & $\begin{array}{l}\text { Dementia delayed } \\
\text { Subarachnoid } \\
\text { haemorrhage }\end{array}$ & $\begin{array}{l}\text { Filling from } R \text { and } \\
\text { from } L \text { on cross } \\
\text { compression }\end{array}$ & $\begin{array}{l}\text { LVA } 6 / 36 \text { con- } \\
\text { stricted field } \\
\text { RVA } 6 / 2 \text { slight } \\
\text { constriction mainly } \\
\text { upper field }\end{array}$ \\
\hline 18 LB 53 yr M & $\begin{array}{l}\text { Anterior } \\
\text { communicating }\end{array}$ & $\begin{array}{l}\text { Downwards, } \\
\text { medially, between } \\
\text { optic } n\end{array}$ & $\begin{array}{l}\text { Chiasma from } \\
\text { below and } \mathbf{R}\end{array}$ & Retro-orbital pain & Filling from $\mathbf{R}$ & $\begin{array}{l}\text { LVA } 6 / 60 \text { incom- } \\
\text { plete temporal } \\
\text { hemianopia } \\
\text { RVA } 6 / 9 \text { upper nasal } \\
\text { quadrantanopia }\end{array}$ \\
\hline 19 FS 62 yr M & $\begin{array}{l}\text { Proximal segment } \\
\text { of } \mathrm{L} \text { ant cerebral } \\
\text { artery }\end{array}$ & $\begin{array}{l}\text { Downwards } \\
\text { medially }\end{array}$ & $\begin{array}{l}\text { Chiasma, } \mathbf{R} \text { optic } \\
\text { nerve }\end{array}$ & $\begin{array}{l}\mathbf{R} \text { frontal headache } \\
\text { Dementia }\end{array}$ & $\begin{array}{l}\text { Aneurysm wall } \\
\text { calcified } \\
\text { Filling from L side }\end{array}$ & $\begin{array}{l}\text { LVA } 6 / 9 \text { lower } \\
\text { temporal loss } \\
\text { RVA finger count- } \\
\text { ing } \\
\text { Upper field loss } \\
\text { temporal > nasal }\end{array}$ \\
\hline
\end{tabular}
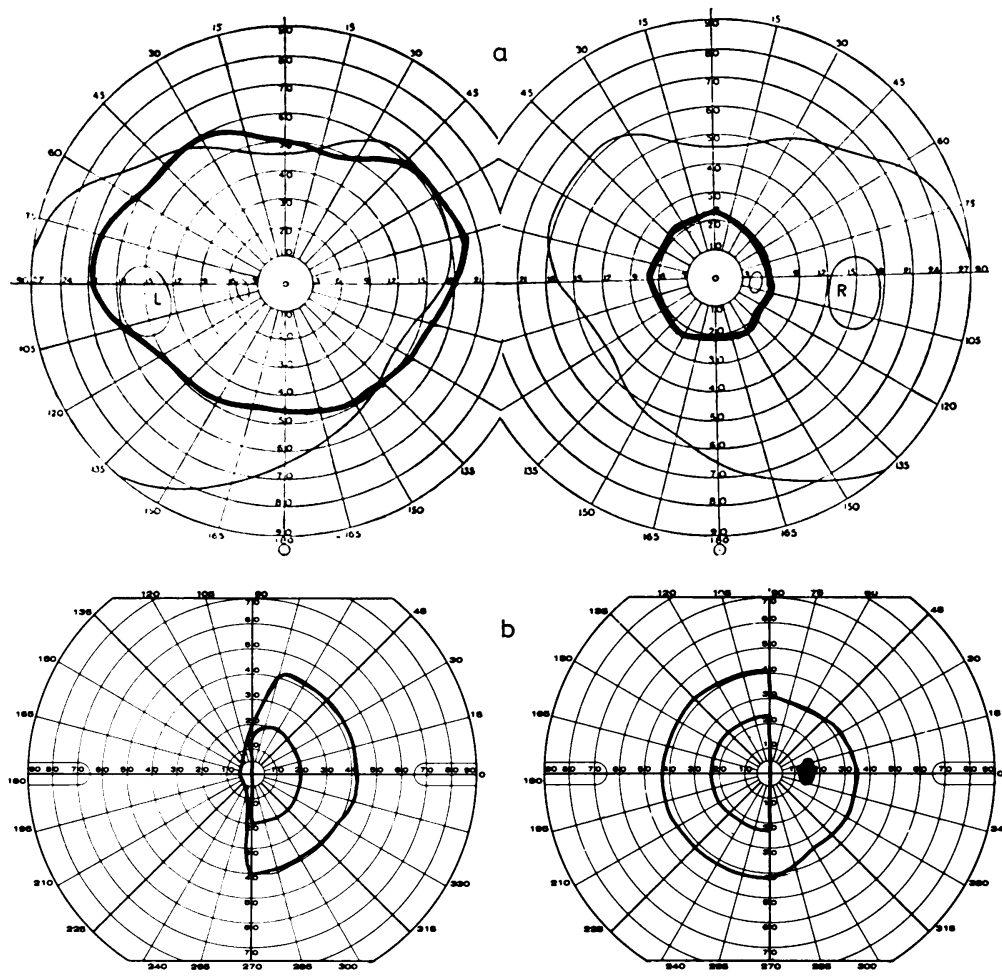

Left

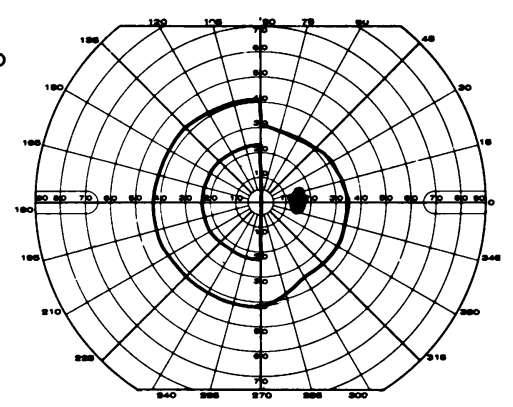

Right
Fig 1 Visual fields on presentation-cavernous group (a) Case 1 VAR 6/60 10/330; $V A L$ 6/24 3/330. (b) Case 2 $V A R \quad 6 / 9$ VAL 6/9 I 2, 4 

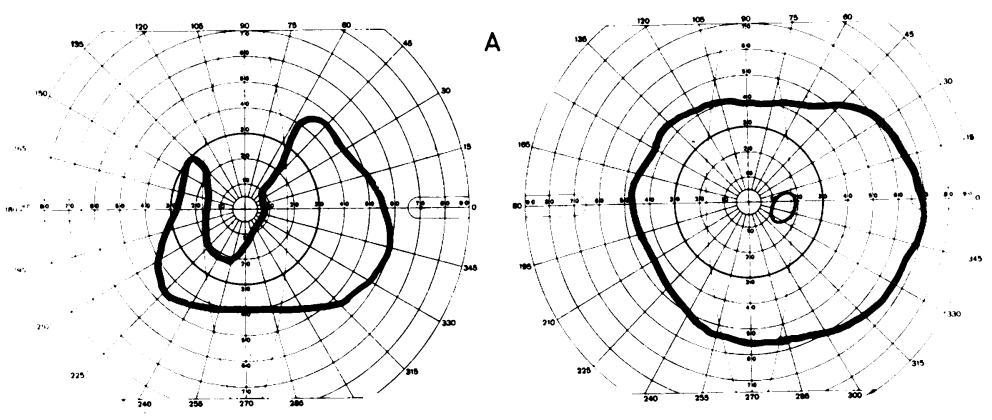

Fig 2 Visual fields on presentation - carotidophthalmic group $(A)$ Case 3

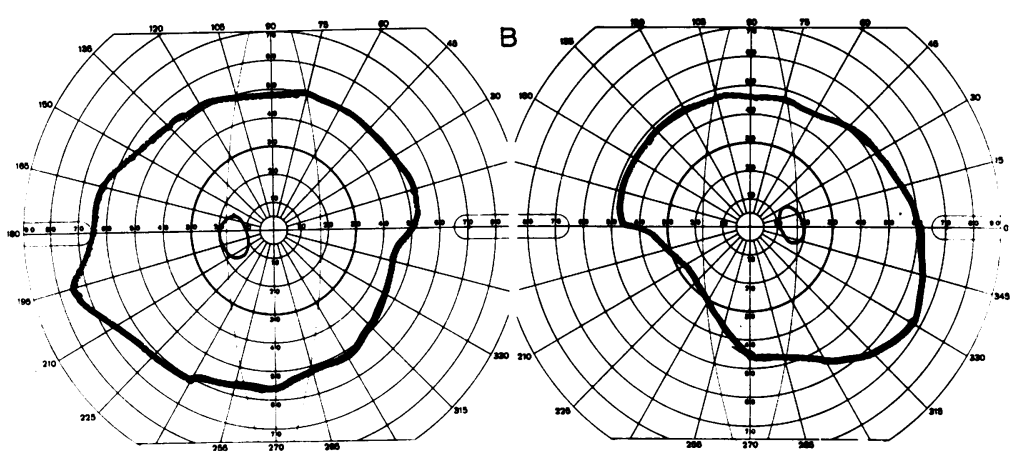

VAR 6/9 I 4; VAL C.F. V 4

(B) Case 4 VAR 6/9 I 4;

$V A L 6 / 6 I 4$.

surgical approach. Follow-up ranged from one to cne and a half years. One patient showed improved vision, three were unchanged.

\section{Discussion}

The anterior part of the Circle of Willis lies immediately above the chiasma and optic nerves while the posterior part lies below and behind. It might be predicted that aneurysms arising from the intracranial carotid artery or from the anterior part of the circle would cause direct pressure on some part of the visual pathway (fig 8). What cannot be predicted however is the effect on vision for, as pointed out by Jefferson, ${ }^{1}$ the direction of growth of aneurysms, particularly those which are large and multilocular, is variable and the effects on the visual pathway may be remote from the site of the aneurysm. While in many instances the optic nerve or chiasma can be seen to be stretched over the aneurysm, compression may not be the sole cause of loss of vision. Distortion or traction and indirect pressure on the nerves at the margins of the optic foramina also play an important part. A further factor is interference with the blood supply of the optic nerve or chiasma through occlusion or distortion of the ophthalmic artery or of one or more of the small vessels arising from terminal carotid, anterior cerebral or posterior communicating to supply the chiasma. The tendency to thrombosis shown by many aneurysms, while reducing the likelihood of haemorrhage, may occlude the origins of branch vessels and contribute to ischaemia. Occasionally there may also be damage from haemorrhage into the neural substance especially if the nerve is adherent to the fundus of the aneurysm.

In the differential diagnosis of lesions in and around the sella there are certain general clinical features which should be taken into consideration. The first is the age and sex of the patient since some types of aneurysm are seen only in the elderly (for example cavernous group) and some show a marked sex predominance (for example carotid ophthalmic group).

Attacks of pain also occur in the history of many patients with aneurysm. The pain is usually unilateral and retro-orbital and may spread to the forehead or into the root of the nose; it is probably due to irritation of the dura in the region of the cavernous sinus. In other patients minor leakage or sudden expansion of an aneurysm may also give rise to episodes of severe retro-orbital pain.

A long history and fluctuation in the physical signs with lengthy periods of spontaneous im- 

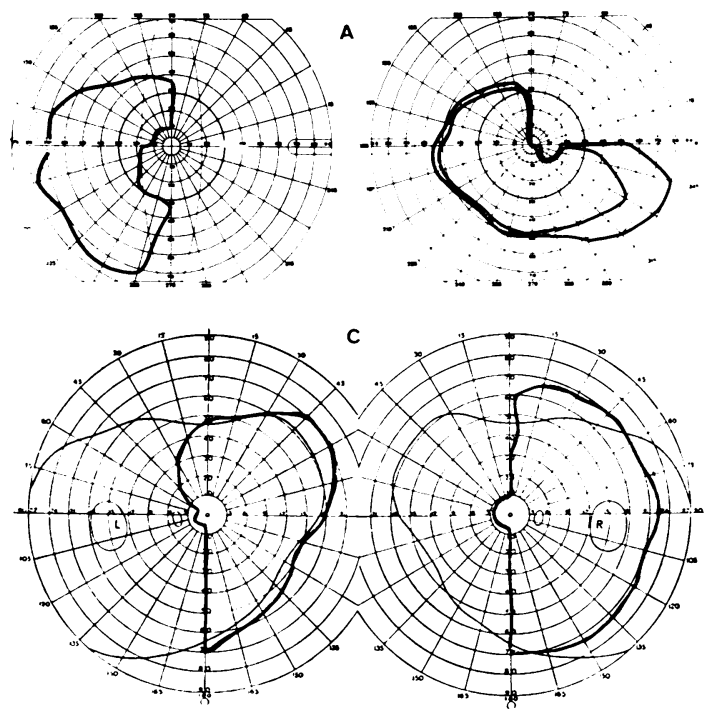
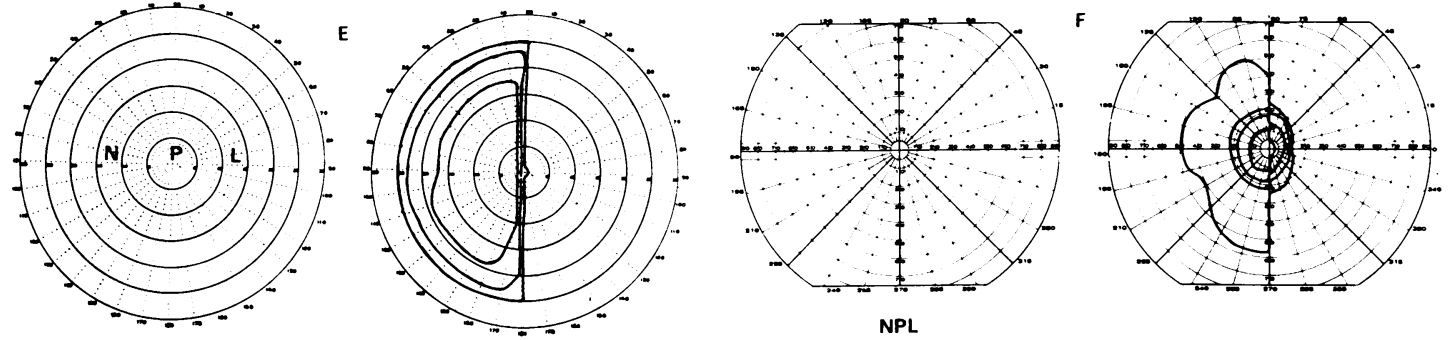

NPL

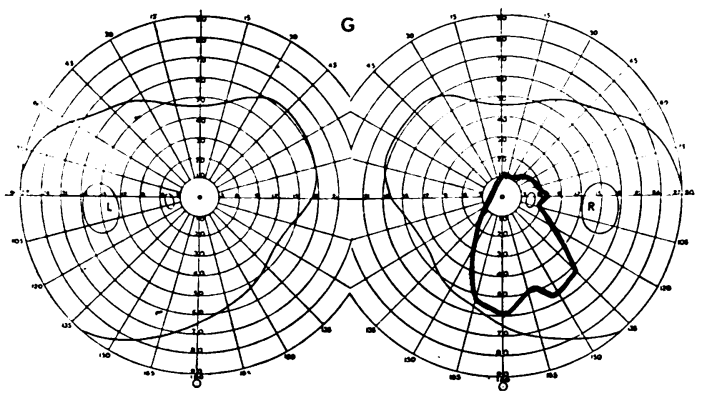

I
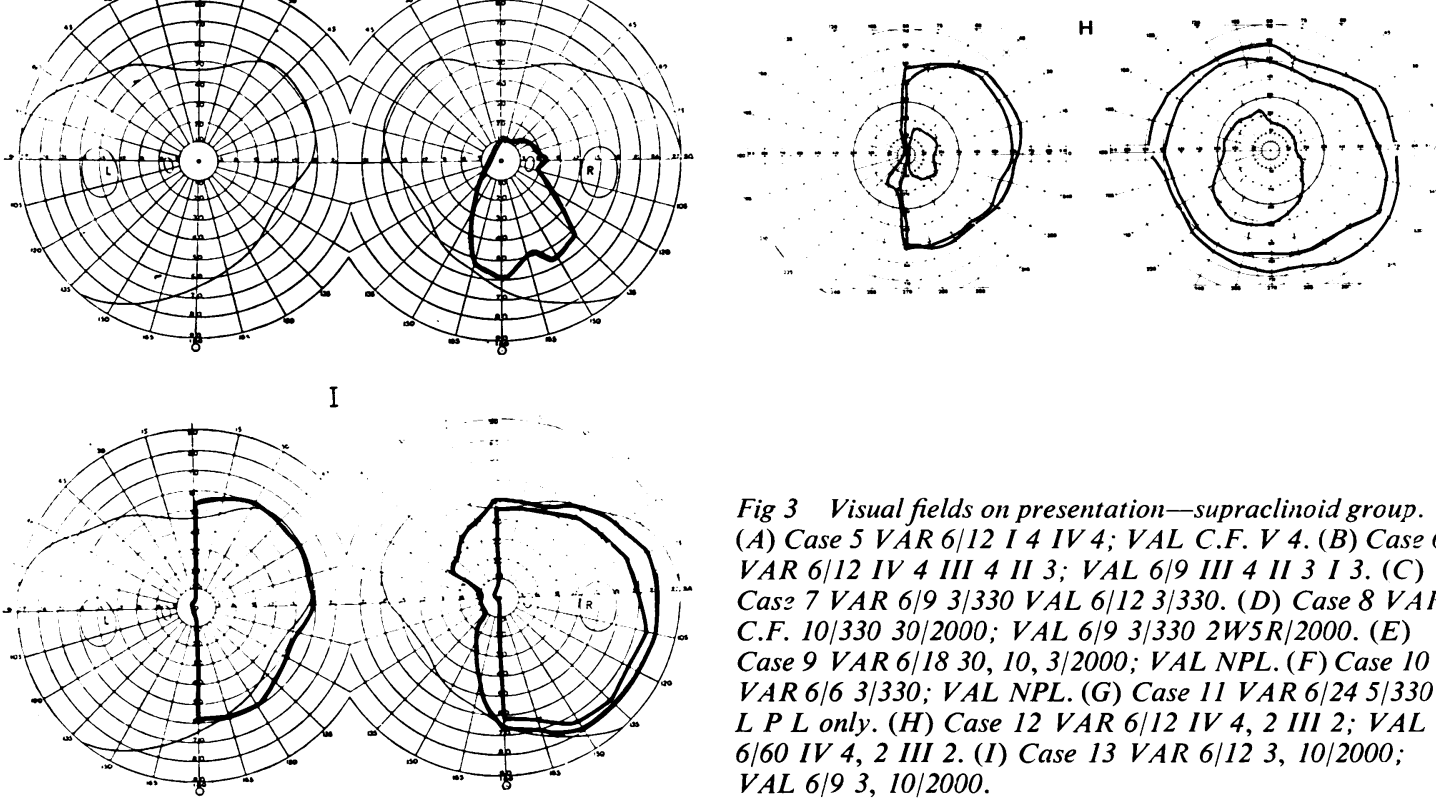

Fig 3 Visual fields on presentation-supraclinoid group (A) Case 5 VAR 6/12 I 4 IV 4; VAL C.F. V 4. (B) Case 6 VAR 6/12 IV 4 III 4 II 3; VAL 6/9 III 4 II 3 I 3. (C) Cas? 7 VAR 6/9 3/330 VAL 6/12 3/330. (D) Case 8 VAR C.F. 10/330 30/2000; VAL 6/9 3/330 2W5R/2000. (E) Case 9 VAR 6/18 30, 10,3/2000; VAL NPL. (F) Case 10 VAR 6/6 3/330; VAL NPL. (G) Case 11 VAR 6/24 5/330; L P L only. (H) Case 12 VAR 6/I2 IV 4, 2 III 2; VAL 6/60 IV 4, 2 III 2. (I) Case 13 VAR 6/12 3, 10/2000; $V A L 6 / 93,10 / 2000$.
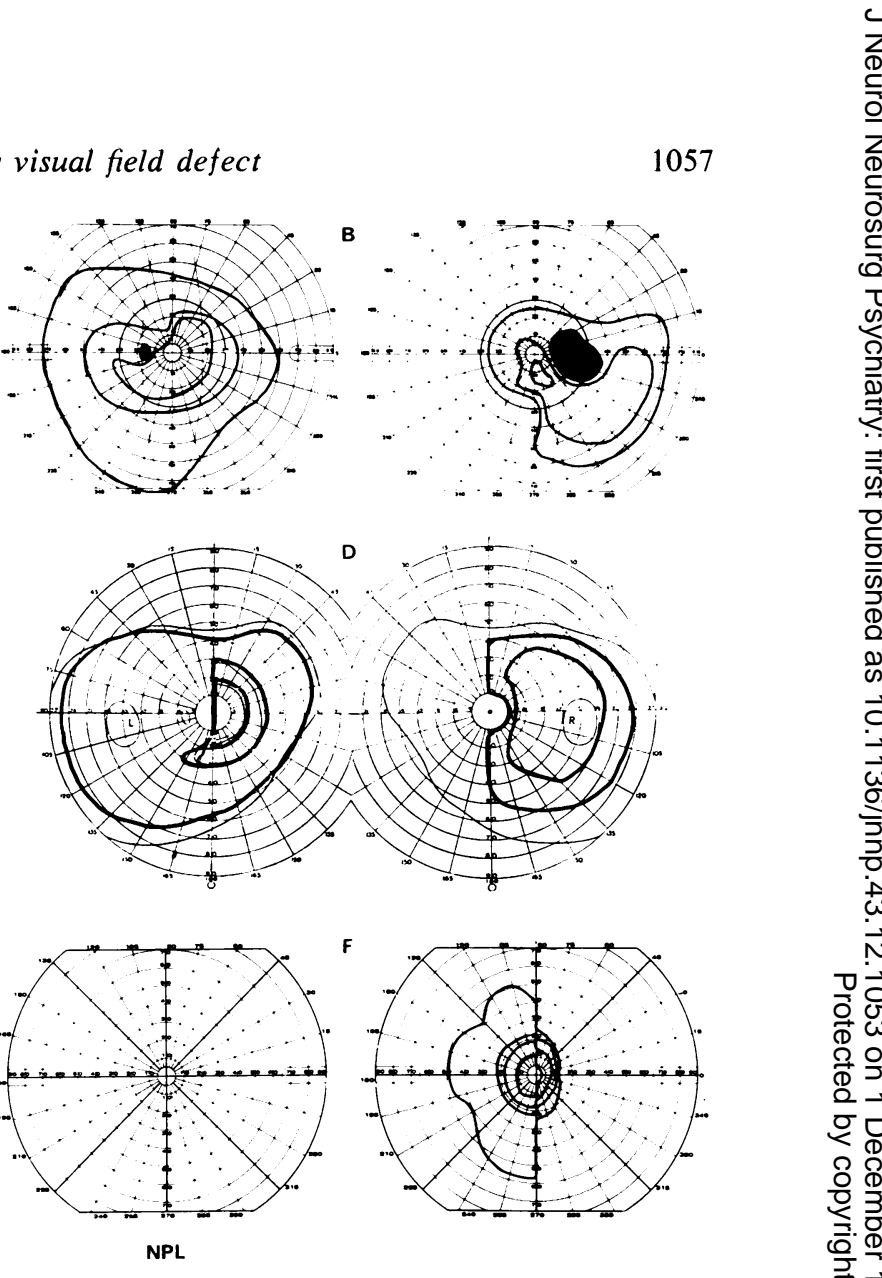

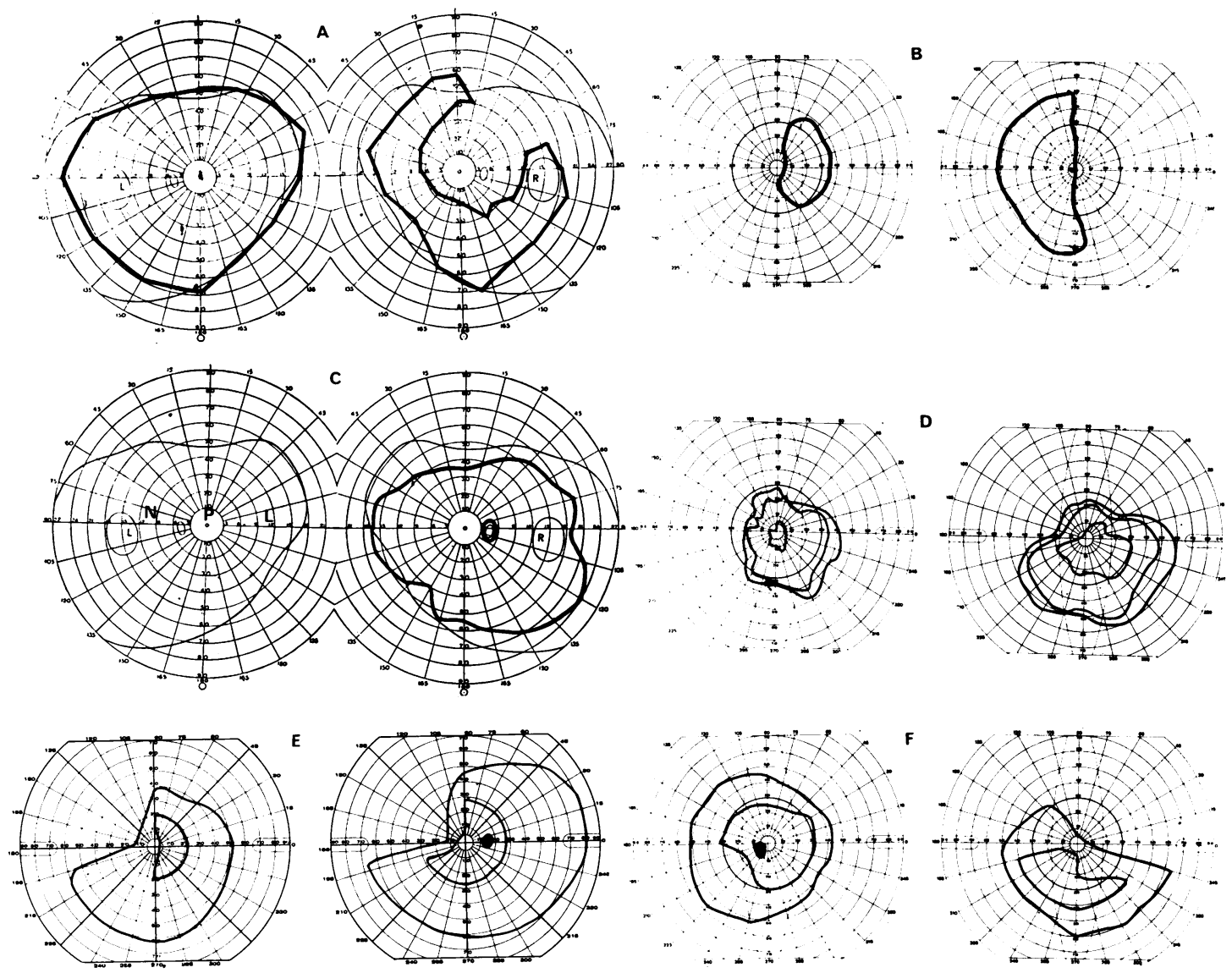

Fig 4 Visual fields on presentation-anterior communicating group. (A) Case 14 VAR C.F. 3/300; VAL 6/6 3/330 (B) Case 15 VAR 6/9 II 4; VAL 6/60 V 4. (C) Case 16 VAR 6/6 II 4; VAL NPL. (D) Case 17 VAR 6/12 IV 4R, 4, 3; VAL 6/36 V 4 R, 4, 3. (E) Case 18 VAR 6/9 3/330, 2/2000; VAL 6/60 10/330 10/2000. (F) Case 19 VAR C.F. 4 III 4; VAL 6/9 V 4 III 4.

provement may also add to the difficulty of diagnosis. This is most noticable in patients with ophthalmoplegia ${ }^{2}$ but variations in the degree of visual impairment was also seen in untreated patients in the present series. A vascular systolic bruit audible over one or both orbits is an unusual but valuable physical sign in giant aneurysm. ${ }^{3}$ It was not heard in any patient in the present series.

\section{Group 1-cavernous aneurysms}

This type of carotid aneurysm, which comprises about $3 \%$ of all aneurysms arising from the carotid system, ${ }^{4}$ is found almost exclusively in elderly women and is formed by an asymmetrical distension of the internal carotid artery within the cavernous sinus. The initial site of expansion, which may be at the origin of a small hypophy- seal branch artery is on the lateral side of the main vessel. As it is enlarges, the aneurysm fills the cavernous sinus, the $3 \mathrm{rd}$ and 4 th nerves coming to lie above the main expansion and the 6th nerve below. ${ }^{5}$ It expands laterally stripping up the dura on the floor of the middle fossa; in a posterior direction enlargement may reach the petrous apex. It may also extend forward to erode the anterior clinaid process, superior orbital fissure and optic foramen. ${ }^{6}$ Medial expansion may cause radiological signs of destruction of the sella and the aneurysm may invade the pituitary fossa before turning upwards to compress the chiasma.

As might be expected from its situation the cavernous aneurysm usually attracts attention as a painful ophthalmoplegia with involvement of the 6th, 3rd, 4th and 5th nerves. Only exception- 

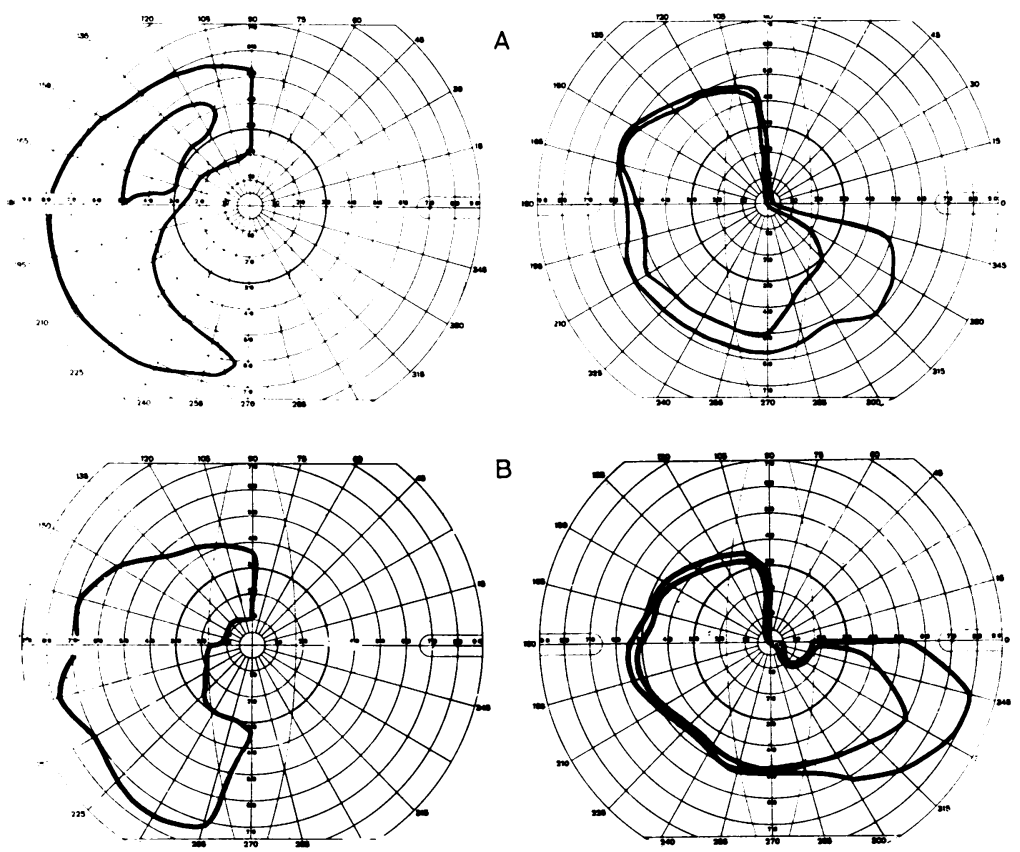

Fig 5 Case 5-Improvement in vision following carotid ligation for supraclinoid aneurysm (a) Pre-operation $V A R$ 6/12 I 4 IV 4; VAL C.F. V 4. (b) One month $\begin{array}{lllll}\text { postoperation } V A R & 6 / 12 I & 1\end{array}$ IV 4; VAL 6/60 V 4 (c) One year postoperation $V A R \quad 6 / 12$ II 4 IV 4 ; VAL 6/36 II 4 IV 2.
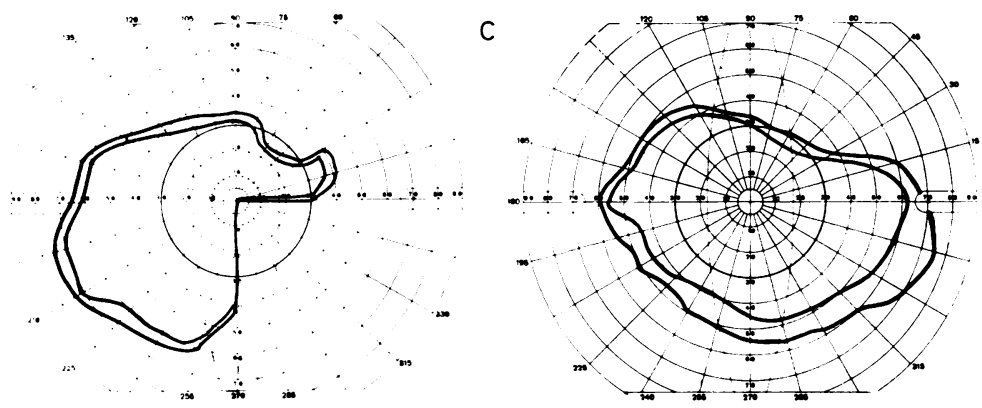

ally does it present initially as a visual defect. Large cavernous aneurysms may go on to a progressive uniocular blindness as the forward extension involves the optic nerve but this usually occurs late in the disease.

The two examples of cavernous aneurysm in the present series were thus highly atypical. In one (case 1) the aneurysm arose from under the artery, just as it entered the sinus. It extended forward underneath the artery, eventually eroding the anterior clinoid process and sphenoid fissure. The patient complained of a painful progressive uniocular visual loss without ophthalmoplegia and on presentation the field showed a general depression with central vision reduced to finger counting. The contralateral field was normal (fig 1a). In the second example (case 2) the aneurysm was dumb-bell shaped. The inferior portion was within the cavernous sinus but the aneurysm then extended through the dura covering the sinus to form a large secondary sac which extended medially and upwards to compress and elevate the back of the optic chiasma in the mid line. The visual field defect was a symmetrical bitemporal hemianopia identical to that seen in many patients with pituitary adenoma (fig 1b).

Group 2-carotid ophthalmic artery aneurysm This type arises in the first $2 \mathrm{~mm}$ of the internal carotid artery above the cavernous sinus and below the origin of the posterior communicating artery. Patients with this type of aneurysm are said to show a high prevalence of multiple aneurysm and there is a strong female preponderance. The aneurysm may extend into and 


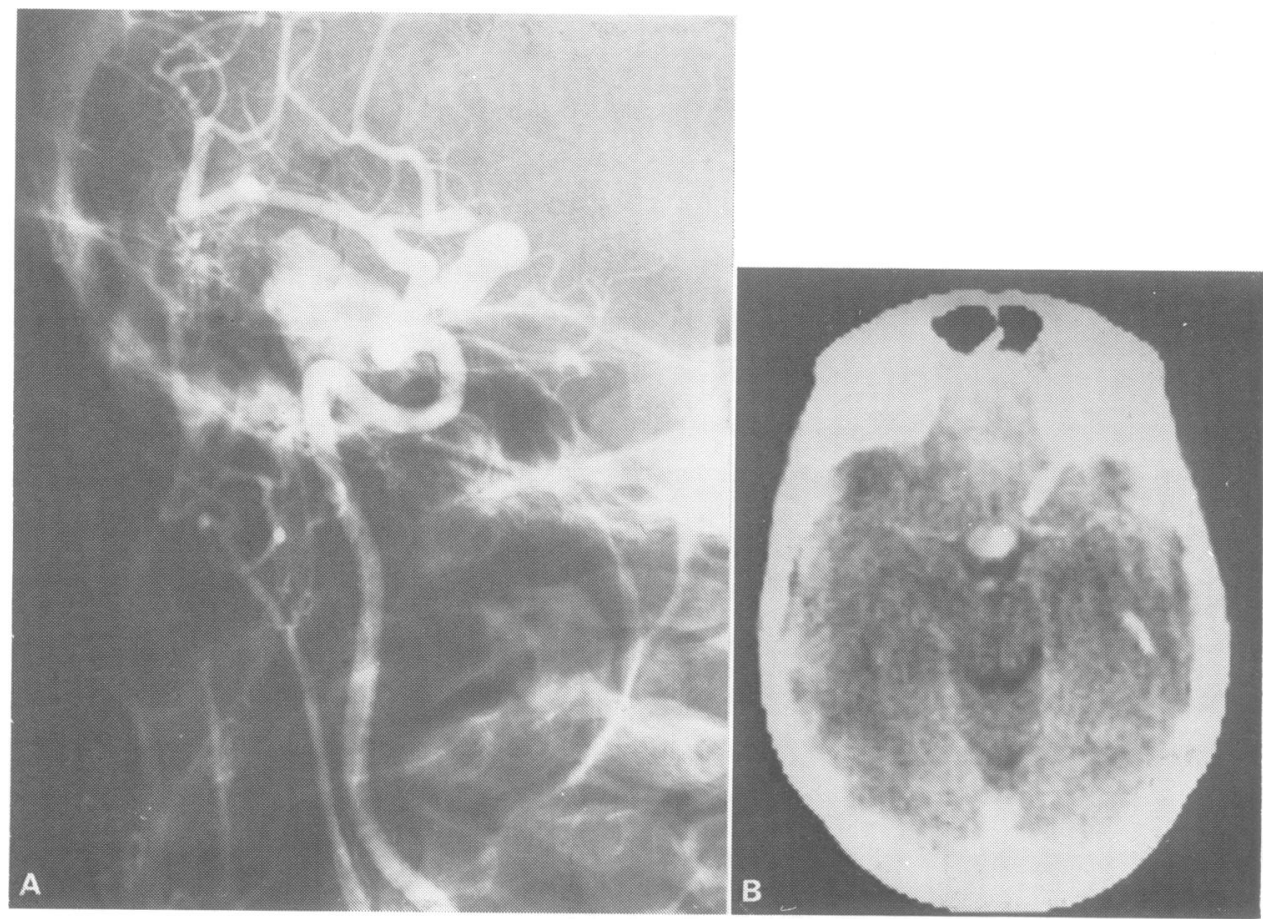

Fig 6 (A) Case 2 cavernous aneurysm extending upward and medially to compress chiasma in midline. (B) Case 2 CT (enhanced) to show position of aneurysm in midline.
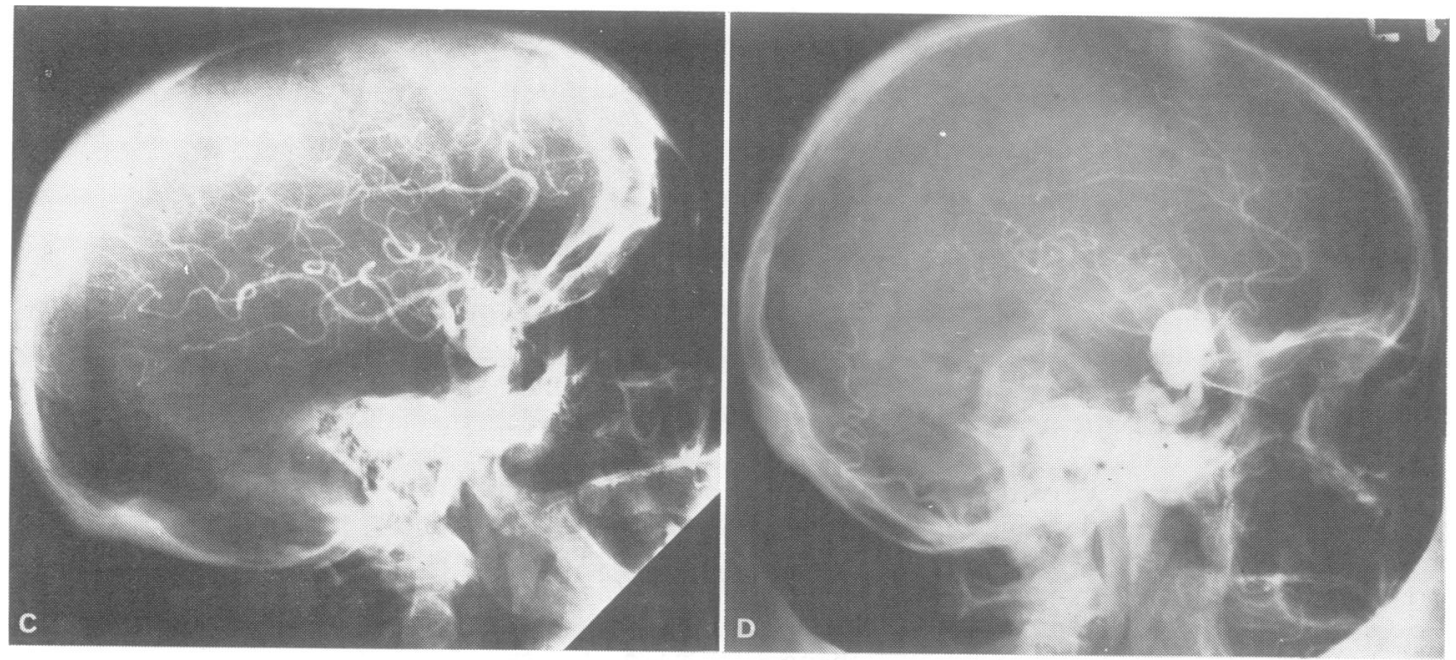

(C) Case 3 Carotid ophthalmic aneurysm causing unilateral optic nerve compression. (D) Case 5 Supraclinoid aneurysm arising in proximal intradural segment of artery and compression optic nerve and lateral chiasma.

dilate the optic canal. Although frequently originating beneath the optic nerve the aneurysm may extend laterally and upwards into the intracranial cavity eroding the anterior clinoid process as it does so. In many cases it may be impossible to distinguish ophthalmic artery aneurysms from those arising in the proximal segment of the internal carotid. 


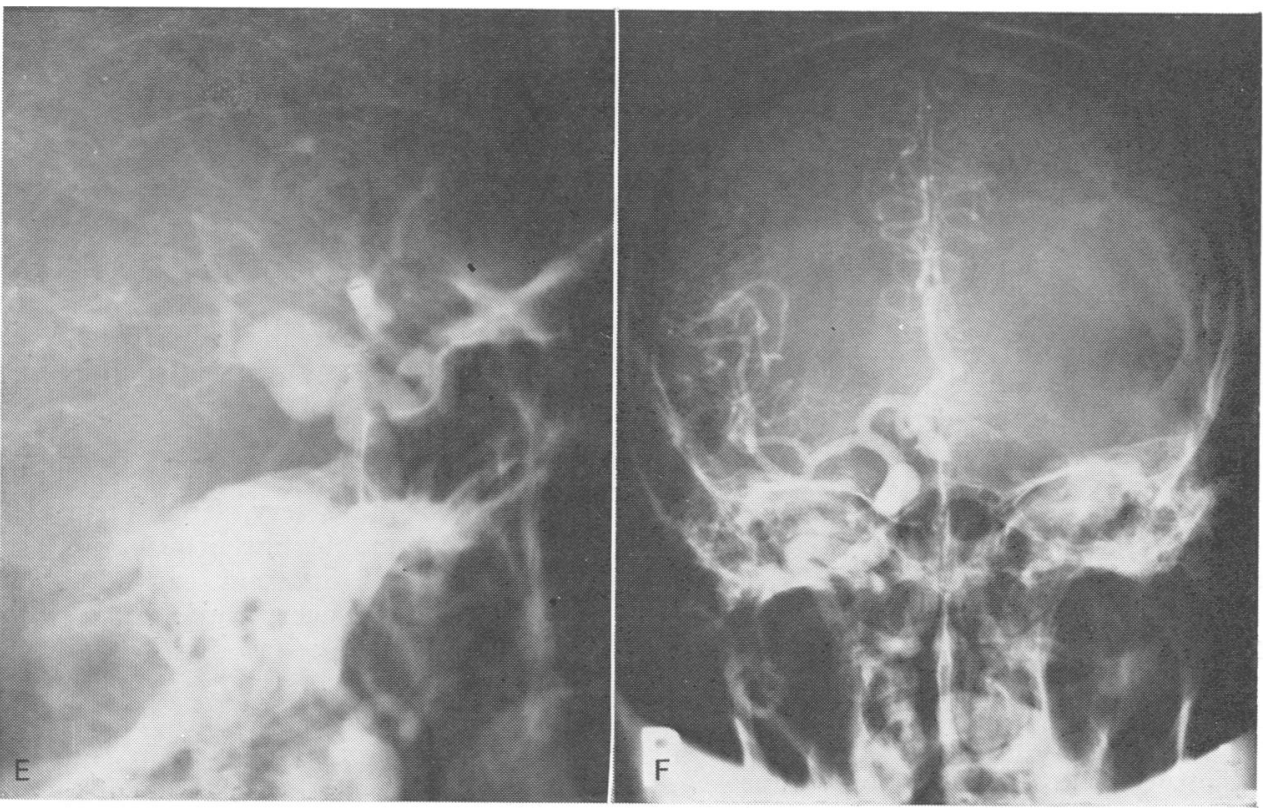

(E) Case 13 Large "posterior communicating" aneurysm expanding medially to compress optic tract. (F) Case 16 Anterior communicating aneursym filling from right carotid artery extending downwards to compress left optic nerve.

Since these aneurysms arise directly beneath the optic nerve they tend to cause early optic nerve compression and to present as uniocular visual loss. The field usually shows a central scotoma tending to break out towards the temporal side. This spreads into the nasal field of the ipsilateral eye followed usually after a long interval by the upper temporal field of the contralateral eye and finally by blindness of the ipsilateral eye. The optic nerve on the affected side at this stage may be flattened and displaced upwards and medially by the aneurysm. A similar pattern of field loss is produced by meningioma. In the two examples of ophthalmic artery aneurysms in the present series, the visual defect at presentation was entirely uniocular, the aneurysm having enlarged upwards and medially to impinge directly on the optic nerve.

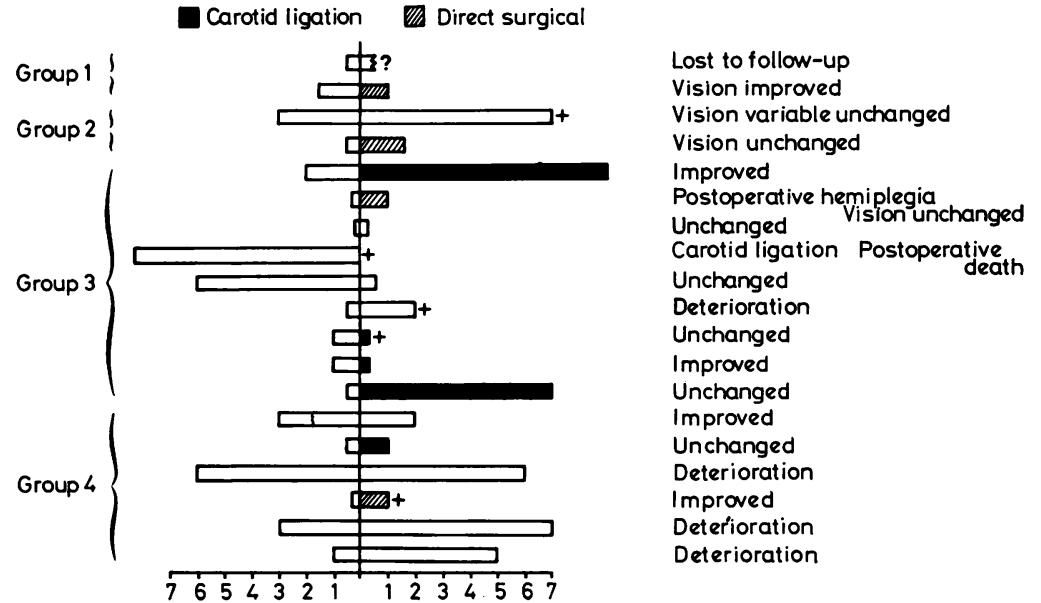

Fig 7 Natural history and results of treatment. Vertical line denotes dates of presentation. Scale in years. 


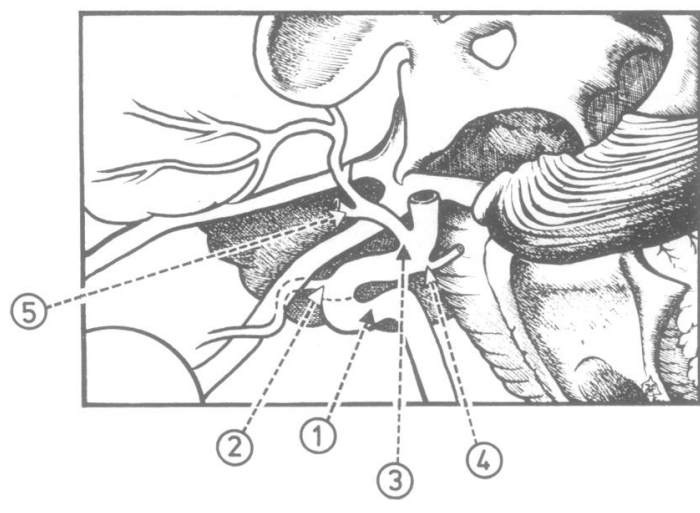

Fig 8 Principal sites of carotid aneurysm (1) cavernous, (2) carotid-ophthalmia, (3) terminal carotid, (4) posterior communicating, (5) anterior communicating.

One patient (fig $2 \mathrm{~A}$ ) had a central scotoma and a visual acuity reduced to finger counting with general depression of the outer isopters. The contralateral eye was normal. The second patient (fig 2B) initially had a lower altitudinal type of field loss which spread to involve central vision and finally spared only a small segment of the nasal field.

\section{Group 3-supraclinoid aneurysms}

Aneurysms arising from the intradural portion of the internal carotid artery are important both as a cause of subarachnoid haemorrhage and of compression of neighbouring structures. Some authors distinguish two varieties, proximal segment aneurysms and aneurysms of the terminal carotid. ${ }^{7}$ Proximal segment aneurysms are immediately related to the optic nerve and lateral side of the chiasma; they may be indistinguishable from ophthalmic artery aneurysms and at an early stage they may possibly originate from small branches passing medially to supply the pituitary stalk. This type characteristically reaches a large size before presentation. It may expand towards the midline displacing the chiasma laterally and elevating it. The dome of the aneurysm may compress the orbital portions of the frontal lobes, the olfactory tracts, the hypothalmus and pituitary stalk. The visual loss produced by this type of aneurysm is highly asymmetrical and is the result both of direct compression of the visual pathways and of angulation of the optic nerve. ${ }^{8}$ Growth is slow and asymmetry may be such that blindness is produced in one eye before involvement of the second eye begins. In contrast to these some authors describe a second variety of aneurysm arising at the carotid bifurcation. ${ }^{78}$ This type tends to expand anteriorly and medially above the chiasma and to mimic a suprasellar tumour. It may cause a bitemporal hemianopia, usually asymmetrical. Posterior expansion of the aneurysm may compress the optic tract.

In the present series of patients, because of the large size of many of the aneurysms, it was not found possible to identify with confidence either radiologically or at surgery the exact site of origin. The supraclinoid carotid aneurysms were therefore considered as a single group. It includes those arising anywhere in the distal two centimetres of the artery, from the origin of the posterior communicating artery and from the bifurcation of the internal carotid artery itself. There were, however, three main categories of visual field loss: (a) optic nerve and lateral chiasmal, (b) suprachiasmal, (c) optic tract.

In the present series the usual direction of enlargement of the supraclinoid aneurysms was upwards and medially to compress the lateral side of the chiasma and optic nerve. Loss of vision in these patients principally affected the ipsilateral eye where there developed a nasal hemianopia and central scotoma. This pattern of field loss is known to occur with a lesion lying lateral to the junction of nerve and chiasma and affecting first uncrossed fibres from the ipsilateral retina. At a later stage the crossing fibres from the contralateral eye, especially those from the lower retina passing most anteriorly in the chiasma, also become involved to produce an upper temporal field loss. The final result may be a blind ipsilateral eye with a contralateral complete temporal hemianopia. This pattern of visual field loss progressing very slowly over many years and sometimes accompanied by periods of unilateral retro-orbital pain appeared to be highly characteristic of aneurysms in this situation and was shown in varying degrees by six patients (cases 5-10) (fig 3A-F).

There were two patients in whom the aneurysm produced a mass lesion above the chiasma rather than on its lateral side. The effects on vision were asymmetrical bitemporal hemianopias more marked on the contralateral eye which was either blind or showed a complete temporal hemianopia (fig 3G, H), Cases 11, 12). The ipsilateral field showed concentric diminution mainly affecting the upper field. One of these patients died and at autopsy the chiasma was found markedly displaced laterally by a large central aneurysm which was also causing traction and direct pressure on both nerves. 
There was only a single example in the present series of an aneurysm apparently arising at the point of origin of the posterior communicating artery rather than at the termination of the carotid (case 13). As pointed out by Jefferson, ${ }^{1}$ these aneurysms seldom produce chiasmal compression because they usually project below and behind the visual pathway. In our patient a large aneurysm had enlarged posteriorly and medially, eventually impinging on the optic tract and causing a complete homonymous hemianopia. Good central vision was retained in each eye (fig $3 \mathrm{~J}$ ).

\section{Group 4-anterior communicating aneurysm}

Aneurysms arising from the anterior communicating artery or from its junction with one or other anterior cerebral artery are the most frequent source of subarachnoid haemorrhage but they are much less important as a cause of local compression before rupture. Of 78 anterior communicating aneurysms reported by Hook and Norlin $^{9}$ only two had visual loss before rupture. This can be ascribed more to a tendency to early rupture than to their situation for they lie in close proximity to and above the optic nerves and chiasma.

The type of visual field loss in reported cases varies widely. Some of Jefferson's patients and one patient reported by Meadows ${ }^{2}$ had a bilateral inferior altitudinal defect such as would be expected from a lesion pressing from above on both optic nerves. Most other authors describe a predominantly uniocular visual loss suggesting pressure on a single optic nerve. Symmetrical visual loss or bitemporal hemianopia is said to be very unusual. ${ }^{10}$ It has also been noted that rapid and complete loss of vision may occur immediately following the rupture of an anterior cerebral artery areurysm, presumably due to pressure or distortion produced by the haematoma.

The findings in the present series differ from previous reports in a number of respects. Firstly the proportion of aneurysms in this group was higher, there being six out of 19 patients all but one of whom were males. There was no fixed pattern of enlargement. In some instances the aneurysm was lobulated and eccentric, sometimes deviating across the mid line to compress the opposite optic nerve (case 16). There was also a tendency for the aneurysm to bulge downwards between the optic nerves thereby stretching and elevating the chiasma. ${ }^{1}$ Displacement of the chiasma also produced indirect effects by pressure on an optic nerve by the anterior cerebral artery or by traction on the nerve causing pressure against the bony edge of the optic foramen.
The pattern of visual loss was highly variable. In no case was there a bilateral lower altitudinal field loss. However, in contrast to other reports, four out of the six patients had bilateral field loss at the time of presentation and in only two instances was the loss purely uniocular (fig 4A, C, cases 14,16 ). Despite the fact that the visual loss was invariably much worse in one eye than the other the more severely affected eye bore little relation to the original side of the aneurysm or to the feeding artery. In case 14 for instance the aneurysm arising on the left anterior cerebral artery displaced the artery backwards causing the anterior cerebral artery to compress and indent the right optic nerve and producing a large central field defect. Other types of field loss were (1) an unusual variety of homonymous defect causing temporal and central field loss on the opposite side and nasal field on the same side (fig 4E, case 18), (2) bilateral contraction of isoptors suggesting bilateral optic nerve compression, worse on the contralateral side (fig 4D, case 17), and (3) an asymmetrical bitemporal hemianopia, the opposite eye having the poorer vision (case 19). The practical lesson when an arteriogram is undertaken to exclude an aneurysm is that unless the aneurysm fills directly or on cross compression it is essential to perform the examination on both sides. Aneurysms of this type may reach a large size, expanding upwards as well as downwards. In the present series there was a high prevalence of associated features such as headache and seizures and three patients showed evidence of dementia and personality change presumably related to direct pressure on the frontal lobes, or to ischaemia in the territory of the anterior cerebral arteries. Subarachnoid haemorrhage was a feature in only one patient who developed this complication after presenting with visual field loss.

\section{Treatment}

Follow up studies emphasise the variable natural history of untreated patients and the difficulty of assessing the effect of treatment. The nine untreated patients mostly showed slow deterioration progressing to complete blindness, but in one patient there was marked fluctuation (case 3) and in one there was spontaneous improvement. Carotid ligation was performed in six patients; massive hemisphere infarction caused postoperative death in one patient, vision improved in two patients and remained unchanged in three. Direct surgical attack on the aneurysm was attempted on four patients with visual improvement in two and no change in two. 
The limited number of patients and the variable natural history of giant aneurysms makes it difficult to assess the efficacy of either of the two major treatments, carotid ligation or direct surgery. It is likely that untreated giant aneurysms continue to become even larger since the majority of such patients deteriorated. It is encouraging that after either type of surgery no patient showed further deterioration of vision although there were three late deaths, four months to seven years after surgery.

Follow up studies suggest that in group 3 aneurysms arising from the supraclinoid portion of the artery, carotid ligation in the neck may be a valuable method of arresting or even reversing visual loss, provided it can be tolerated without producing cerebral infarction. By contrast in the single instance of attempted direct surgical approach to an aneurysm in this site there was a severe postoperative hemiplegia probably due to propagation of thrombus in the terminal carotid artery adjacent to the aneurysm.

It is also clear from our results that considerable operative morbidity and mortality attaches to direct surgery on aneurysms of the anterior communicating complex but at this site where carotid ligation in the neck has a relatively small effect on pressure within an aneurysm the direct approach seems the only procedure capable of preserving vision and preventing local compression of the frontal lobes.
Dr Peiris was the holder of a Commonwealth Fellowship from the Nuffield Foundation.

We are grateful to Professor Lindsay Symon for co-operation and advice.

\section{References}

1 Jefferson G. Further observations concerning compression of the optic pathways by intracranial aneurysms. Proc Cong Neurol Surg 1955; 1:55-103.

2 Meadows SP. Intracranial aneurysms. In: Modern Trends in Neurology, Vol. 1, Feiling A, ed. London: Butterworth, 1952.

3 Meadows SP. Intracavernous aneurysms of the internal carotid. Arch Ophthalmol 1959; 62: 566-74.

4 Pool LJ, Potts DG. Aneurysm and Arteriovenous anomalies of the Brain. New York: Harper and Row, 1965.

5 Barr HWK, Blackwood W, Meadows SP. Intracavernous carotid aneurysms: a clinical-pathological report. Brain 1971; 94:607.

6 Bull J. Massive aneurysms at the base of the base of the brain. Brain 1969; 92:535-70.

7 Walsh FB, Hoyt WF. Clinical Neuro-ophthalmology. Baltimore: Williams Wilkin, 1969.

8 Bird AC, Nolan B, Gargano D. Unruptured aneurysms of the supraclinoid carotid artery. Neurology 1970; 20:445-54.

9 Hook O, Norlin G. Acta Neurol Scand 1964; 40: 200-18.

10 Glaser JS. Neuro-Ophthalmology. New York: Harper and Row, 1977. 